DOE/ID-22231

Prepared in cooperation with the U.S. Department of Energy

\title{
Measurement of Unsaturated Hydraulic Properties and Evaluation of Property-Transfer Models for Deep Sedimentary Interbeds, Idaho National Laboratory, Idaho
}

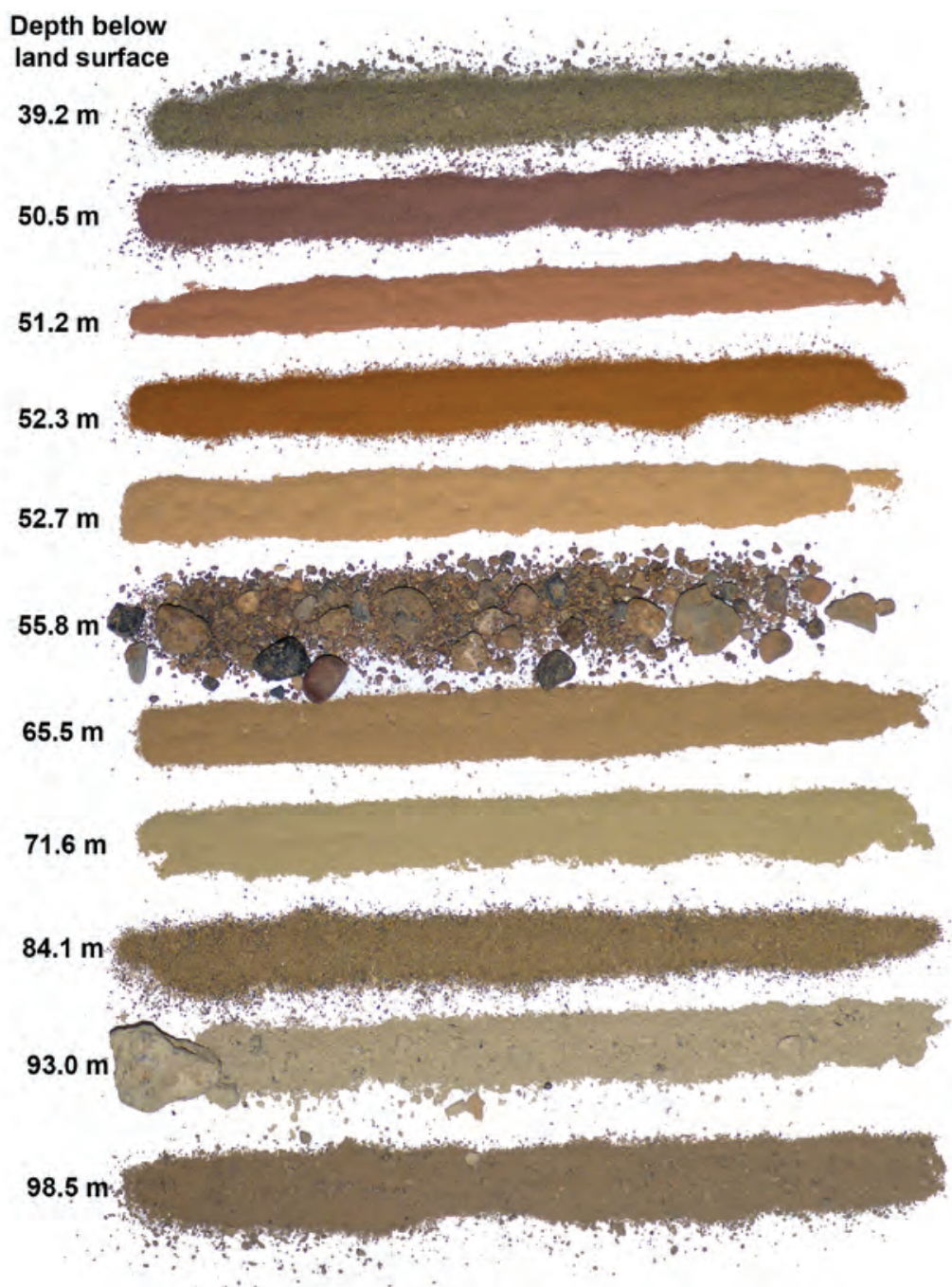

Scientific Investigations Report 2014-5206 
Cover: Selected sediments from borehole USGS-140. Photograph taken by Kim S.

Perkins, U.S. Geological Survey. 


\section{Measurement of Unsaturated Hydraulic Properties and Evaluation of Property- Transfer Models for Deep Sedimentary Interbeds, Idaho National Laboratory, Idaho}

By Kim S. Perkins, Benjamin B. Mirus, and Brittany D. Johnson

DOE/ID-22231

Prepared in cooperation with the U.S. Department of Energy

Scientific Investigations Report 2014-5206 


\title{
U.S. Department of the Interior SALLY JEWELL, Secretary
}

\section{U.S. Geological Survey \\ Suzette M. Kimball, Acting Director}

\author{
U.S. Geological Survey, Reston, Virginia: 2014
}

For more information on the USGS - the Federal source for science about the Earth, its natural and living resources, natural hazards, and the environment, visit http://www.usgs.gov or call 1-888-ASK-USGS.

For an overview of USGS information products, including maps, imagery, and publications, visit http://www.usgs.gov/pubprod

To order this and other USGS information products, visit http://store.usgs.gov

Any use of trade, firm, or product names is for descriptive purposes only and does not imply endorsement by the U.S. Government.

Although this information product, for the most part, is in the public domain, it also may contain copyrighted materials as noted in the text. Permission to reproduce copyrighted items must be secured from the copyright owner.

Suggested citation:

Perkins, K.S., Mirus, B.B., and Johnson, B.D., 2014, Measurement of unsaturated hydraulic properties and evaluation of property-transfer models for deep sedimentary interbeds, Idaho National Laboratory, Idaho: U.S. Geological Survey Scientific Investigations Report 2014-5206, 16 p., http://dx.doi.org/10.3133/sir20145206.

ISSN 2328-0328 (online) 


\section{Contents}

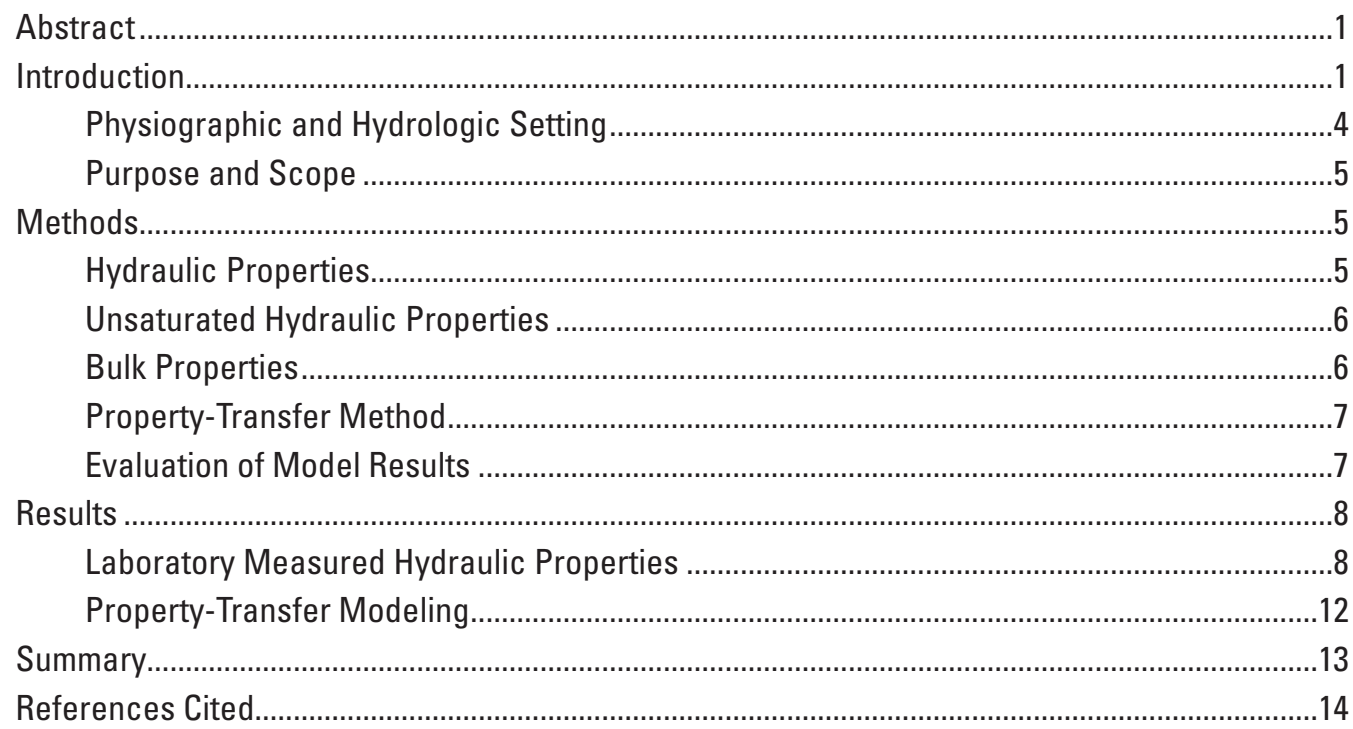

\section{Figures}

1. Map showing location of the Idaho National Laboratory and selected facilities,

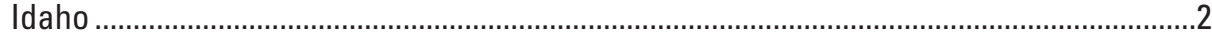

2. Map showing location of borehole USGS-140, Idaho National Laboratory, Idaho............3

3. Conceptual model of subsurface showing potential unsaturated zone flow paths, eastern Snake River Plain, Idaho .....................................................................................

4. Graphs showing measured unsaturated hydraulic conductivity curves for samples from borehole USGS-140, Idaho National Laboratory, Idaho …………............................10

5. Graph showing measured water retention curves for samples from borehole USGS-140, Idaho National Laboratory, Idaho .............................................................10

6. Graph showing measured particle size distributions for core samples from borehole USGS-140, Idaho National Laboratory, Idaho.

7. Graph showing observed and property transfer model predicted saturated water content, saturated hydraulic conductivity, and Rossi-Nimmo model parameters 


\section{Tables}

1. USGS-140 core sample bulk properties and saturated hydraulic conductivity, Idaho National Laboratory, Idaho...

2. USGS-140 core sample hydraulic properties and van Genuchten (1980) parameters (the scaling parameter, in units of $1 /$ centimeter) and $n$ (the shape parameter, unitless) , Idaho National Laboratory, Idaho.

3. Texture and textural class information for core and bulk samples from USGS-140, Idaho National Laboratory, Idaho

\section{Conversion Factors, Datums, and Abbreviations and Acronyms}

\section{Conversion Factors}

\begin{tabular}{|c|c|c|}
\hline Multiply & By & To obtain \\
\hline \multicolumn{3}{|c|}{ Length } \\
\hline millimeter (mm) & 0.03937 & inch (in.) \\
\hline centimeter (cm) & 0.3937 & inch (in.) \\
\hline kilometer (km) & 0.6214 & mile (mi) \\
\hline meter (m) & 3.281 & foot $(\mathrm{ft})$ \\
\hline \multicolumn{3}{|c|}{ Area } \\
\hline square centimeter $\left(\mathrm{cm}^{2}\right)$ & 0.001076 & square foot $\left(\mathrm{ft}^{2}\right)$ \\
\hline square kilometer $\left(\mathrm{km}^{2}\right)$ & 247.1 & acre \\
\hline square kilometer $\left(\mathrm{km}^{2}\right)$ & 0.3861 & square mile $\left(\mathrm{mi}^{2}\right)$ \\
\hline \multicolumn{3}{|c|}{ Volume } \\
\hline milliliter (mL) & 0.0338 & ounce, fluid (fl. oz) \\
\hline liter $(\mathrm{L})$ & 2.113 & pint (pt) \\
\hline liter $(\mathrm{L})$ & 1.057 & quart (qt) \\
\hline liter (L) & 0.2642 & gallon (gal) \\
\hline \multicolumn{3}{|c|}{ Flow rate } \\
\hline cubic meter per second $\left(\mathrm{m}^{3} / \mathrm{s}\right)$ & 35.314 & cubic feet per second $\left(\mathrm{ft}^{3} / \mathrm{s}\right)$ \\
\hline \multicolumn{3}{|c|}{ Mass } \\
\hline gram (g) & 0.03527 & ounce, avoirdupois (oz) \\
\hline \multicolumn{3}{|c|}{ Pressure } \\
\hline centimeter of water (cm-water) & 0.01419 & pound per square inch $\left(\mathrm{lb} / \mathrm{in}^{2}\right)$ \\
\hline \multicolumn{3}{|c|}{ Density } \\
\hline gram per cubic centimeter $\left(\mathrm{g} / \mathrm{cm}^{3}\right)$ & 62.4220 & pound per cubic foot $\left(\mathrm{lb} / \mathrm{ft}^{3}\right)$ \\
\hline \multicolumn{3}{|c|}{ Hydraulic conductivity } \\
\hline meter per day (m/d) & 3.281 & foot per day (ft/d) \\
\hline
\end{tabular}

Temperature in degrees Celsius $\left({ }^{\circ} \mathrm{C}\right)$ may be converted to degrees Fahrenheit $\left({ }^{\circ} \mathrm{F}\right)$ as follows:

$$
{ }^{\circ} \mathrm{F}=\left(1.8 \times{ }^{\circ} \mathrm{C}\right)+32
$$




\title{
Conversion Factors, Datums, and Abbreviations and
} Acronyms

\section{Datums}

Vertical coordinate information is referenced to the North American Vertical Datum of 1988 (NAVD 88).

Horizontal coordinate information is referenced to the North American Datum of 1927 (NAD 27).

\author{
Abbreviations and Acronyms \\ DOE U.S. Department of Energy \\ ESRP Eastern Snake River Plain \\ INL Idaho National Laboratory \\ INTEC Idaho Nuclear Technology and Engineering \\ Center \\ RHLLW Remote Handled Low-Level Waste \\ RMSE root-mean-square error \\ RWMC Radioactive Waste Management Complex \\ USGS U.S. Geological Survey
}





\title{
Measurement of Unsaturated Hydraulic Properties and Evaluation of Property-Transfer Models for Deep Sedimentary Interbeds, Idaho National Laboratory, Idaho
}

\author{
By Kim S. Perkins, Benjamin B. Mirus, and Brittany D. Johnson
}

\section{Abstract}

Operations at the Idaho National Laboratory (INL) have the potential to contaminate the underlying Eastern Snake River Plain (ESRP) aquifer. Methods to quantitatively characterize unsaturated flow and recharge to the ESRP aquifer are needed to inform water-resources management decisions at INL. In particular, hydraulic properties are needed to parameterize distributed hydrologic models of unsaturated flow and transport at INL, but these properties are often difficult and costly to obtain for large areas. The unsaturated zone overlying the ESRP aquifer consists of alternating sequences of thick fractured volcanic rocks that can rapidly transmit water flow and thinner sedimentary interbeds that transmit water much more slowly. Consequently, the sedimentary interbeds are of considerable interest because they primarily restrict the vertical movement of water through the unsaturated zone. Previous efforts by the U.S. Geological Survey (USGS) have included extensive laboratory characterization of the sedimentary interbeds and regression analyses to develop property-transfer models, which relate readily available physical properties of the sedimentary interbeds (bulk density, median particle diameter, and uniformity coefficient) to water retention and unsaturated hydraulic conductivity curves.

During 2013-14, the USGS, in cooperation with the U.S. Department of Energy, focused on further characterization of the sedimentary interbeds below the future site of the proposed Remote Handled Low-Level Waste (RHLLW) facility, which is intended for the long-term disposal of low-level radioactive waste. Twelve core samples from the sedimentary interbeds from a borehole near the proposed facility were collected for laboratory analysis of hydraulic properties, which also allowed further testing of the property-transfer modeling approach. For each core sample, the steady-state centrifuge method was used to measure relations between matric potential, saturation, and conductivity. These laboratory measurements were compared to water-retention and unsaturated hydraulic conductivity parameters estimated using the established property-transfer models. For each core sample obtained, the agreement between measured and estimated hydraulic parameters was evaluated quantitatively using the Pearson correlation coefficient (r).
The highest correlation is for saturated hydraulic conductivity $\left(K_{\text {sat }}\right)$ with an $r$ value of 0.922 . The saturated water content $\left(\mathrm{q}_{\text {sat }}\right)$ also exhibits a strong linear correlation with an $\mathrm{r}$ value of 0.892 . The curve shape parameter $(\lambda)$ has a value of 0.731 , whereas the curve scaling parameter $\left(\mathrm{y}_{0}\right)$ has the lowest $r$ value of 0.528 . The $r$ values demonstrate that model predictions correspond well to the laboratory measured properties for most parameters, which supports the value of extending this approach for quantifying unsaturated hydraulic properties at various sites throughout INL.

\section{Introduction}

The Idaho National Laboratory (INL) was established in 1949 under the U.S. Atomic Energy Commission, now the U.S. Department of Energy (DOE), for nuclear energy research. INL occupies about 2,300 $\mathrm{km}^{2}$ of the west-central part of the eastern Snake River Plain (ESRP) (fig. 1). The site hosts several facilities, of which at least four have been used to generate, store, or dispose of radioactive, organic, and inorganic wastes. These facilities include the (1) Radioactive Waste Management Complex (RWMC); (2) Advanced Test Reactor (ATR) Complex, formerly known as the Test Reactor Area (TRA); (3) Test Area North (TAN); and (4) Idaho Nuclear Technology and Engineering Center (INTEC); formerly known as the Idaho Chemical Processing Plant (ICPP). Future plans for development at INL include the establishment of a Remote Handled Low-Level Waste (RHLLW) management facility, which will be used for the long-term disposal of low-level radioactive waste, and will be located approximately $3.2 \mathrm{~km}$ northwest of INTEC and $0.4 \mathrm{~km}$ southwest of ATR (fig. 2). Previous operations at these INL facilities have introduced radionuclide contaminants into the unsaturated subsurface and the ESRP aquifer, which poses a threat to the water quality in the aquifer (U.S. Department of Energy, 2004, 2007). Quantitative methods for characterizing the complex vadose zone beneath the RHLLW facility are needed to assess potential scenarios for contaminant transport and inform future regulatory decisions. 


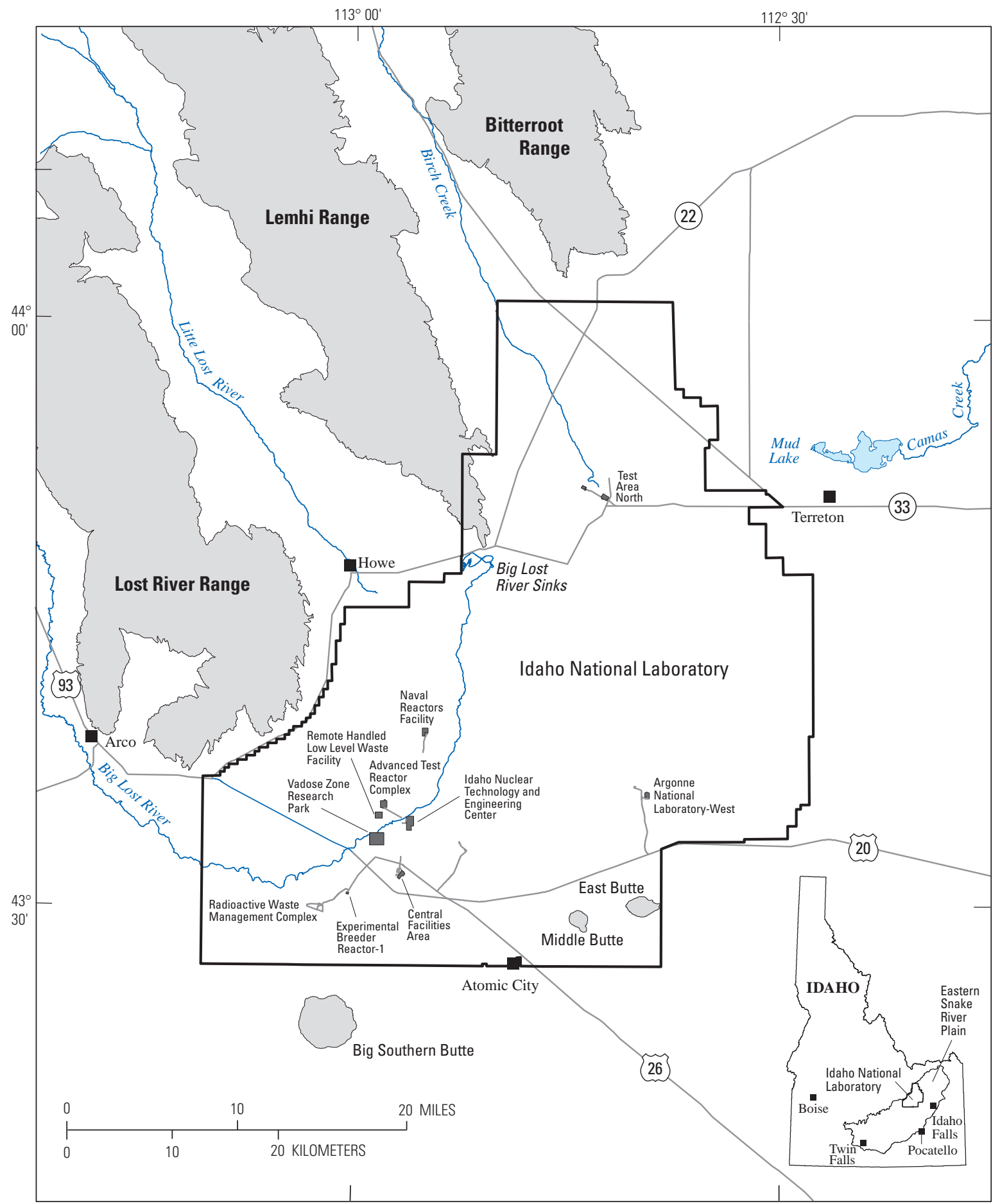

Base from U.S. Geological Survey, 1:100,000, Arco quadrangle, 1989, Blackfoot quadrangle, 1997, Borah Peak quadrangle, 1989, Circular Butte quadrangle, 1980, Craters of the Moon quadrangle, 1978, and Dubois quadrangle, 1983

Figure 1. Location of the Idaho National Laboratory and selected facilities, Idaho. 


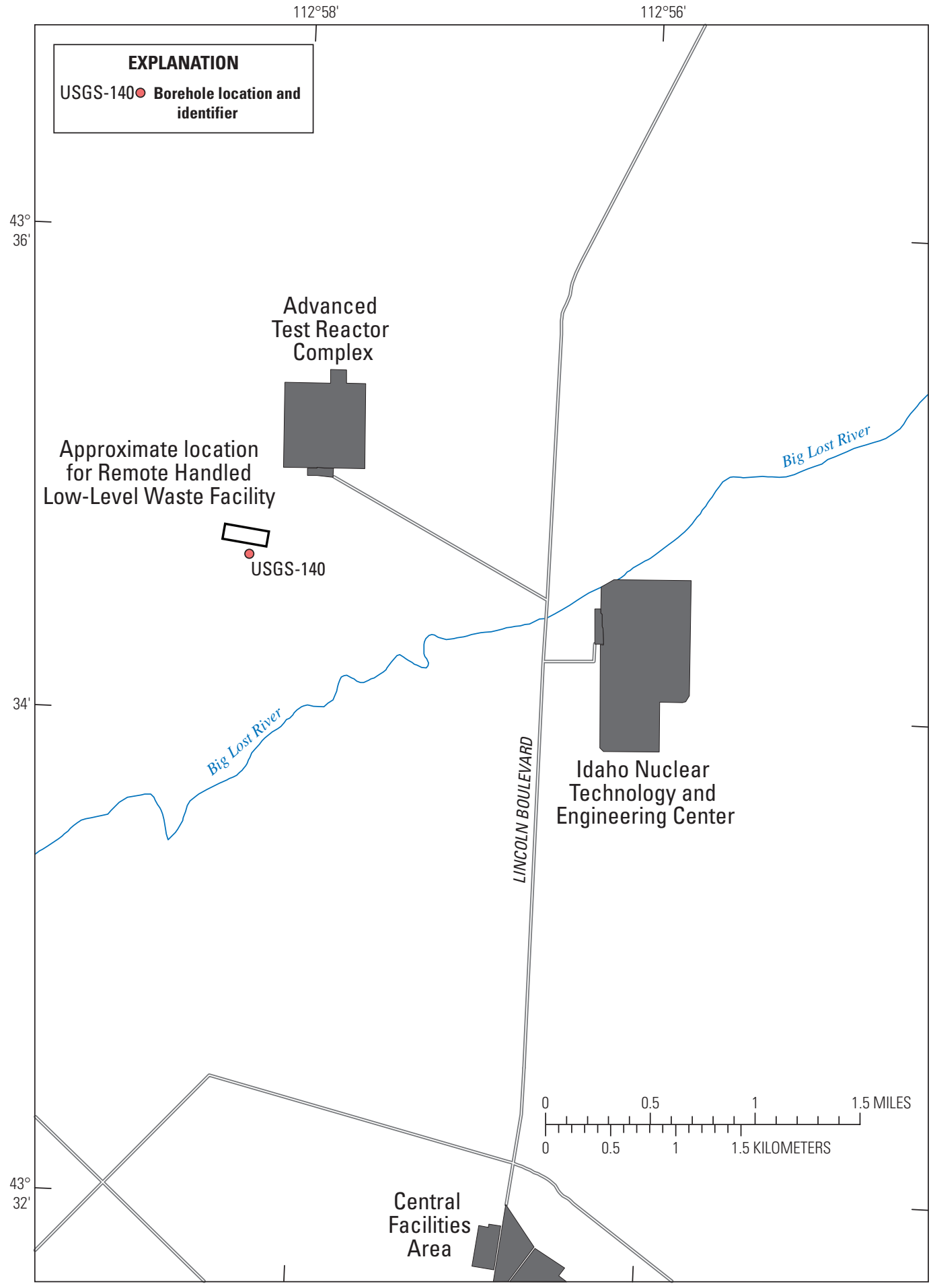

Base from U.S. Geological Survey digital data, 1:24,000 and 1:100,000.

Universal Transverse Mercator projection, Zone 12. Datum is North American Datum of 1927.

Figure 2. Location of borehole USGS-140, Idaho National Laboratory, Idaho. 


\section{Physiographic and Hydrologic Setting}

The ESRP lies within a northeast-trending basin, approximately $320 \mathrm{~km}$ long and $80-110 \mathrm{~km}$ wide, which slopes gently to the southwest and is bordered on the northwest and southeast by the northwest-trending mountain ranges (fig. 1). The ESRP is underlain by interbedded volcanic and sedimentary layers that extend as much as $3,000 \mathrm{~m}$ below the land surface. The sedimentary interbeds are the products of quiet intervals between volcanic eruptions and are of fluvial, eolian, and lacustrine origin, with large amounts of sand, silt, and clay. Volcanic units primarily consist of basalt flows, welded ash flows, and rhyolite; range from vesicular to massive with either horizontal or vertical fracture patterns. Near the RHLLW facility, boreholes drilled to 200-m depths penetrate a sequence of 23 basalt-flow groups and 15-20 sedimentary interbeds (Anderson, 1991). The surficial sediments at the nearby INTEC facility consist of gravelly alluvium, range from 2 to $20 \mathrm{~m}$ thick, and are thickest to the northwest (Anderson and others, 1996).
The climate of the ESRP is semiarid, and the average annual precipitation is $0.22 \mathrm{~m}$ (Department of Energy, 1989). Parts of the ESRP aquifer underlie INL, and depths to the regional water table range from $61 \mathrm{~m}$ in the north to about $274 \mathrm{~m}$ in the south and about $145 \mathrm{~m}$ in the region beneath RHLLW (Davis and others, 2013). At borehole USGS-140, the measured water table depth at the time of completion was about $149.4 \mathrm{~m}$ below land surface (Twinning and others, 2014). The predominant direction of groundwater flow within the aquifer is from northeast to southwest, but is generally in the southern direction south of the ATR Complex. Recharge is primarily from: irrigation water diversions from streams; precipitation and snowmelt; underflow from tributary-valley streams; and seepage from surface water bodies (Hackett and others, 1986). Recharge fluxes to the ESRP aquifer are largely controlled by the alternating stratigraphy of fractured volcanic rocks and sedimentary interbeds within the overlying vadose zone (U.S. Department of Energy, 2004). The fractured rocks facilitate rapid preferential flow and transport downward through the vadose zone, whereas the lower permeability interbeds impede vertical fluxes (ig. 3).

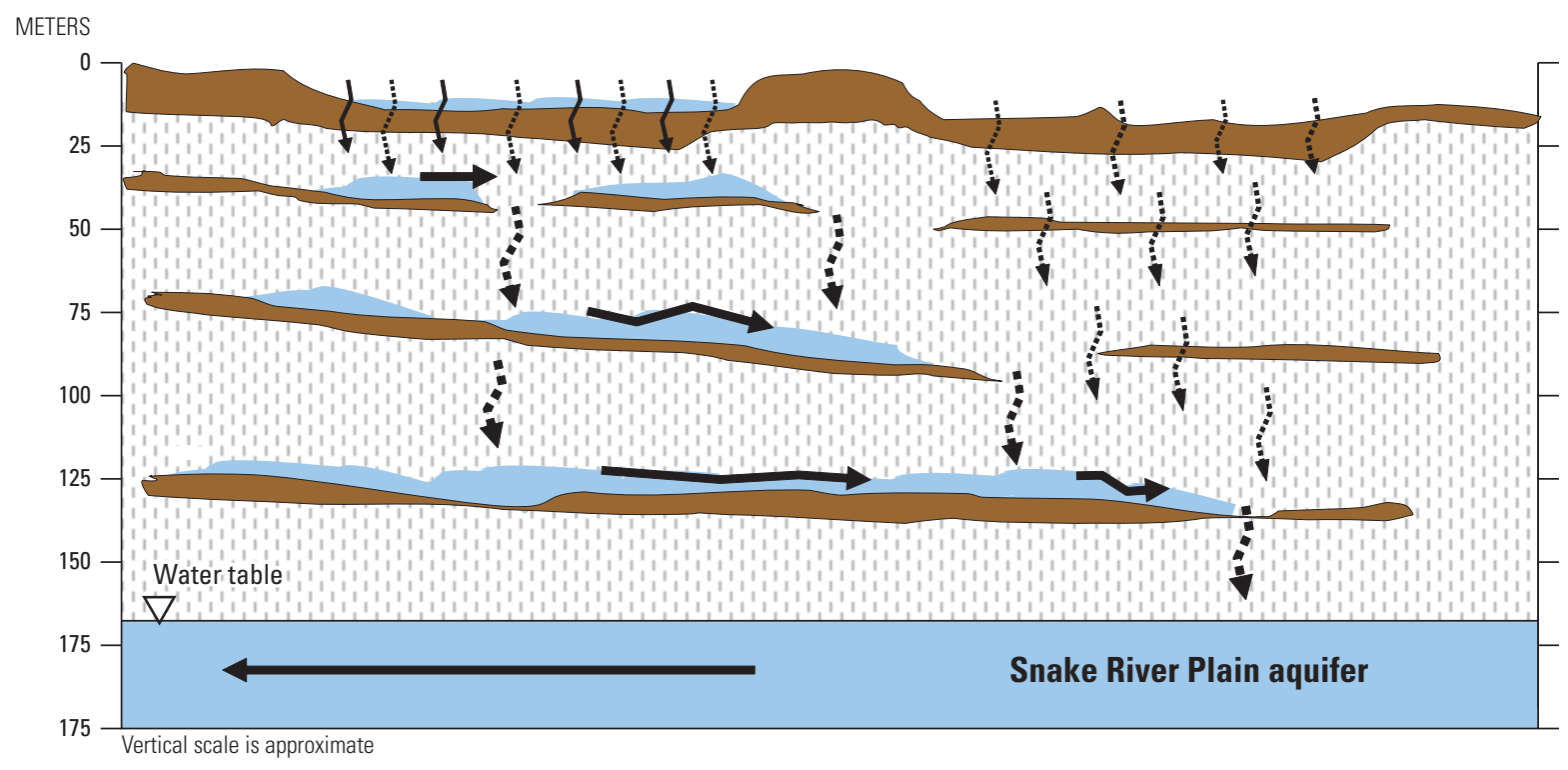

\section{EXPLANATION}

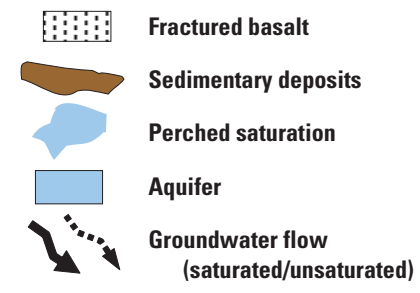

Figure 3. Conceptual model of subsurface showing potential unsaturated zone flow paths, eastern Snake River Plain, Idaho. 


\section{Purpose and Scope}

The main purpose of this report is to characterize the deep sedimentary material collected at borehole USGS-140 in the vicinity of the proposed RHLLW facility. These data will provide valuable information for modeling flow thorough the unsaturated zone and quantifying the relative importance of preferential and diffuse components of flow. Previous efforts at characterizing the unsaturated zone at INL by the U.S. Geological Survey (USGS) have focused on the hydraulic properties of the sedimentary interbeds at other locations within the INL (Perkins and Nimmo, 2000; Perkins, 2003; Winfield, 2003) and on the development of site-specific property-transfer models (PTM) (Winfield, 2005; Perkins and Winfield, 2007; Perkins, 2008), which together provide a firm foundation for large-scale simulation of water and contaminant transport using traditional numerical models based on Richards' (1931) equation. In the work presented here, we conduct detailed characterization of the sedimentary interbeds below the RHLLW facility using similar laboratory measurement techniques as the previous studies and quantitatively evaluate the utility of these previously established property-transfer models.

\section{Methods}

Upon completion of drilling through sediments in borehole USGS-140 (fig. 2), core sections were selected at the INL Core Library for transport back to the Unsaturated Flow Processes Laboratory in Menlo Park, California. Because the Steady-State Centrifuge (SSC) method (Nimmo and others, 1994, 2002) was used to determine the unsaturated hydraulic properties, it was first necessary to select intervals suitable for recoring samples into the centrifuge retainers. The best possible intervals were chosen based on the appearance of the material through the transparent plastic $\left(\operatorname{Lexan}^{\circledR}\right)$ core liners (for example, intervals with the fewest number of fractures or that appeared most undisturbed and cohesive). Core sections, typically 10 -cm-long, were created by cutting the liners perpendicular to their lengths using an electric rotary hand tool. To aid in separating the short sections from the long sections after cutting through the liners, a wetting solution ( $0.3 \mathrm{ml}$ sodium hypochlorite per liter of tap water) was applied to the cuts using a squirt bottle. Samples for the SSC method were then collected using a sharpedged recoring device designed specifically for minimal disturbance sampling. Core trimmings were saved for later determination of bulk properties, such as particle density and particle-size distribution.

\section{Hydraulic Properties}

After recoring and prior to measurement of saturated hydraulic conductivity $\left(K_{\text {sat }}\right)$, each sample (in centrifuge retainers) was placed in a dish of the wetting solution with the level filled to the top of the retainer. A wetting solution concentration of $0.3 \mathrm{ml}$ sodium hypochlorite per liter of tap water was used throughout the experiments, including during the determination of unsaturated conductivity values, in order to inhibit bacterial growth within the soil pores. Saturated water contents were calculated on a volume basis by subtracting the oven-dry weight of the core from the wet weight (with samples weighed after $K_{\text {sat }}$ determination) and dividing by the initial volume of the sample in the centrifuge retainer.The standard falling-head method was used for $K_{\text {sat }}$ measurement (Klute and Dirksen, 1986) where $K_{\text {sat }}$ is calculated by:

$$
K_{\text {sat }}=\left(\frac{a L}{A \Delta t}\right) \ln \left(\frac{H_{i}}{H_{f}}\right)[\mathrm{cm} / \mathrm{s}]
$$

where

$a \quad$ is the cross-sectional area of the burette that supplies the water $\left(\mathrm{cm}^{2}\right)$,

A is the cross-sectional area of the sample $\left(\mathrm{cm}^{2}\right)$,

$L \quad$ is the sample length (cm),

$H_{i}$ and $H_{f} \quad$ are the initial and final heights of water in the burette $(\mathrm{cm})$, and

$\Delta t \quad$ is the time it takes for the burette level to drop from $H_{i}$ to $H_{f}$ (s). 


\section{Unsaturated Hydraulic Properties}

The Steady-State Centrifuge method (Nimmo and others, 1994; 2002) uses centrifugal force to desaturate samples and define the unsaturated hydraulic conductivity relations, $K(\theta)$ and $K(\psi)$. If the matric pressure within the sample is constant over the sample length, then unsaturated conductivity points that define the $K(\theta)$ relation can be determined by varying the centrifuge speed and pump flow rates until a constant water content is achieved. Darcy's law with the gravitational force term replaced by a centrifugal force term is:

$$
q=\frac{Q}{A}=-K_{v}\left(\frac{d \psi_{v}}{d r}-\rho_{w} \omega^{2} r\right)[\mathrm{cm} / \mathrm{s}]
$$

where

$$
\begin{aligned}
& Q \quad \text { is the flow rate of the pump that supplies } \\
& \text { water to the sample }\left(\mathrm{cm}^{3} / \mathrm{s}\right) \text {, } \\
& \text { A is the cross-sectional area of the sample }\left(\mathrm{cm}^{2}\right) \text {, } \\
& K_{v} \quad \text { is the unsaturated hydraulic conductivity per } \\
& \text { unit volume }\left(\mathrm{cm}^{3} \mathrm{~s} / \mathrm{g}\right) \text {, } \\
& \psi_{v} \quad \text { is the matric potential (energy per unit } \\
& \text { volume) (dynes } \left./ \mathrm{cm}^{2}\right) \text {, } \\
& \rho_{w} \quad \text { is the density of water }\left(\mathrm{g} / \mathrm{cm}^{3}\right) \text {, } \\
& \omega \text { is the angular velocity of the centrifuge } \\
& \text { (radians per second), and } \\
& r \quad \text { is the radius from the center of the centrifuge } \\
& \text { rotor to the midpoint of the sample }(\mathrm{cm}) \text {. }
\end{aligned}
$$

For $d \psi / d r<<\rho_{\mathrm{w}} \omega^{2} r, K_{v}(\psi)$ is approximated by $\mathrm{q} /\left(\rho_{\mathrm{w}} \omega^{2} \mathrm{r}\right)$. Converting to units of pressure head (energy per unit weight), where $K_{w} \equiv K_{v} \rho_{w} g$, this relation becomes $K_{w}(\psi) \approx(q g) /\left(\omega^{2} r\right)$ with $K_{w}$ expressed in $\mathrm{cm} / \mathrm{s}$.

A Beckman Instruments model J-6M centrifuge with an Unsaturated Flow Apparatus (UFA) rotor (Conca and Wright, 1998) was used in the method. Infusion pumps were used to deliver water to core samples while subjected to centrifugal force. Two samples of similar texture were run simultaneously, starting from saturation (as determined by the falling-head methods described previously) and desaturating in increments determined by varying the pump rate and centrifuge speed. The steady-state criterion was achieved when the sample weight remained constant after repeated spinning of the centrifuge at the same speed and using the same pump flow rate.

After determining the steady-state water content associated with a given unsaturated hydraulic conductivity, the sample was removed from the centrifuge to measure the equilibrium matric pressure, $\psi$, using a tensiometer. Pairing the average water content of the sample with the equilibrium pressure yielded a point on the drying retention curve.
An average of eight matric pressure measurements was determined per sample. A matric pressure value of $-0.1 \mathrm{~cm}$-water was assumed at saturation. The range of unsaturated $K$ values achieved with the method ranged from $10^{-4}$ to $10^{-9} \mathrm{~cm} / \mathrm{s}$. The number of values of unsaturated $K$ varied depending on the sample texture, with finer samples having fewer points. Saturated water contents were calculated using the initial bulk density of the sample (after measurement of $K_{\text {sat }}$ ), while unsaturated water contents were calculated using the final bulk density (after completion of all measurements) as there were some occurrences of minor compaction in the centrifuge.

\section{Bulk Properties}

Bulk density, $\rho_{b}$, was determined by dividing the ovendry weight of the recored sample by the total volume. The total volume was calculated from the dimensions of the centrifuge retainer (3.33 cm diameter and $4.9 \mathrm{~cm}$ length, on average), with the sample length adjusted for a top recess. Recesses were estimated by taking an average of several measurements over the sample surface with a depth micrometer. The particle density for each sample, $\rho_{s}$, was measured by the pycnometer method, after Blake and Hartge (1986), using representative splits of the air-dried core trimmings. Total porosity was then calculated from the relation $\Phi=1-\left(\rho_{b} / \rho_{s}\right)$. Initial bulk densities and porosities were determined prior to the determination of unsaturated hydraulic properties in the centrifuge and final values were determined after all centrifuge measurements were completed.

Particle-size distributions were measured for the 12 core samples using excess material saved during sample recoring. Additional particle-size distributions were measured on bulk samples taken from intervals that were not used for hydraulic property measurements.

Prior to particle-size determination, samples were air-dried and then physically disaggregated using a rubbertipped pestle and ceramic mortar. A 16-part spinning riffler was used to accurately create small representative splits for use in an optical analyzer (Coulter ${ }^{\circledR}$ LS 230 Series). Some samples contained particles greater than $2 \mathrm{~mm}$, therefore sieving was required prior to splitting. The presence of basalt fragments usually occurred near the interface of the sediment with a basalt layer. Because these were not depositional clasts, basalt fragments were not considered part of a sample particle-size distribution.

The Coulter ${ }^{\circledR}$ LS 230 is a commercially available device used for measuring particle sizes ranging from $4 \times 10^{-5} \mathrm{~mm}$ to $2 \mathrm{~mm}$. The device uses a laser to scatter light through a sample suspended in filtered tap water (Gee and Or, 2002). As the 
sample is circulated through a transparent cell, the diffraction pattern from the laser is measured by a series of detectors. A mathematical algorithm (Fraunhofer diffraction model) is used to convert the diffraction pattern into particle sizes, assuming spherically shaped particles. On a logarithmic scale, the bin size, or Dd interval, is defined as $\log \left(\mathrm{d}_{\text {upper }}\right)-\log \left(\mathrm{d}_{\text {lower }}\right)$, or $\log \left(\mathrm{d}_{\text {upper }} / \mathrm{d}_{\text {lower }}\right)$, where $\mathrm{d}_{\text {upper }}$ represents the upper bin limit and $\mathrm{d}_{\text {lower }}$ represents the lower bin limit in terms of particle diameter. By default, the device determines the frequency of particles falling within 116 different bins, with an average geometric bin size $(\Delta d)$ of 0.041 .

Subsamples on the order of $0.5-1 \mathrm{~g}$ were used depending on texture. Sonication during loading of the samples and before each analysis was used to further disperse aggregates. The particle-size distribution of each sample was measured at least three times, with the average of the best three sequential runs used as the final particle-size distribution of the sample.

\section{Property-Transfer Method}

An alternative to measuring the unsaturated hydraulic properties of core samples in the laboratory is to develop a PTM that can predict these properties from more easily measured bulk physical properties, such as bulk density $\left(\rho_{\text {bulk }}\right)$, particle density $\left(\rho_{\text {part }}\right)$, and particle-size distribution. Hydraulic PTMs have been developed for the sedimentary interbeds at the INL (Winfield, 2005). These types of models are a cost effective way to estimate unsaturated hydraulic properties for use in flow models, to predict contaminant travel times and flow paths, and to provide greater understanding of unsaturated flow processes in the complex unsaturated zone at the INL. Property-transfer modeling is a useful approach to estimating hydraulic properties, even when the estimates have a large margin of error, because hydraulic-property measurements cannot be made for every point in space. Winfield (2005) describes in detail types and uses of propertytransfer models.

To develop PTMs for the INL sedimentary interbeds, Winfield (2005) used multiple linear-regression equations to estimate hydraulic properties (measurements of $\theta_{\text {sat }}$ and $K_{\text {sat }}$, and curve-fit parameters for $\theta[\psi]$ ) from linear combinations of bulk physical properties ( $\rho_{\text {bulk }}, \rho_{\text {part }}$, and particle-size parameters). To estimate the entire $\theta(\psi)$ curve from saturation to oven dryness, the Rossi-Nimmo (Rossi and Nimmo, 1994) junction model was used to characterize the $\theta(\psi)$ measurements. Multiple linear-regression equations then were developed for each of the three parameters defining the Rossi-Nimmo junction model. These model parameters are: (1) saturated water content $\left(\theta_{\text {sat }}\right),(2)$ the scaling factor for $\psi$ $\left(\psi_{0}\right)$, and (3) the curve-shape parameter $(\lambda)$. Sometimes, $\psi_{0}$ is associated with $\psi$ at which air first enters a porous material during desaturation (referred to as "air-entry pressure"). In this study, the units of $\psi_{0}$ are expressed in centimeters of water (cm-water). The curve-shape parameter $\lambda$ indicates the relative steepness of the middle portion of the $\theta(\psi)$ curve, described by the power-law function. The regression equations used to estimate $\theta_{\text {sat }}, \psi_{0}, \lambda$, and $K_{\text {sat }}$ require $\rho_{\text {bulk }}$, the median particle diameter, and the uniformity coefficient (an indication of the spread in the particle size distribution) as explanatory variables. Perkins and Winfield (2007) further extended the Winfield (2005) PTM to predict unsaturated hydraulic conductivity using a capillary bundle model.

\section{Evaluation of Model Results}

To evaluate the property-transfer model performance, modeled and observed values of $\mathrm{q}_{\mathrm{sa}}, K_{\mathrm{sa}}, \lambda$, and $\mathrm{y}_{\mathrm{o}}$ were compared statistically by two methods. The Root Mean Square Error (RMSE) is a frequently used measure of the difference between values predicted by a model and the values actually observed. These individual differences also are called residuals, and the RMSE serves to aggregate them into a single measure of predictive power. The RMSE of a model prediction with respect to the estimated variable $X_{\text {model }}$ is defined as the square root of the mean squared error:

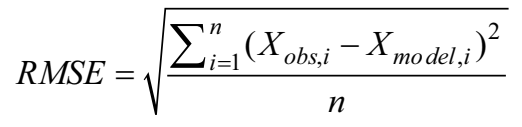

where

$$
\begin{array}{cl}
X_{\text {obs }} & \text { is each observed parameter value, and } \\
X_{\text {model }} & \text { is each modeled parameter value. }
\end{array}
$$

The lower the value, the better the agreement between the observed and predicted parameter values.

The Pearson correlation coefficient was used to indicate the strength and direction of the linear relationship between the model output and the observed parameter values. The coefficient, $r$, is obtained by dividing the covariance of the two variables by the product of their standard deviations:

$$
r=\frac{\sum_{i=1}^{n}\left(x_{i}-\bar{x}\right) \times\left(y_{i}-\bar{y}\right)}{\sqrt{\sum_{i=1}^{n}\left(x_{i}-\bar{x}\right)^{2} \times \sum_{i=1}^{n}\left(y_{i}-\bar{y}\right)^{2}}}
$$

A correlation of +1 means a perfect increasing linear relationship and -1 means a perfect decreasing linear relationship and the values in between indicate the degree of linear relationship between model and observations; a value of 0 indicates no correlation. 


\section{Results}

\section{Laboratory Measured Hydraulic Properties}

The properties measured in this study include: bulk density $\left(\rho_{b}\right)$, particle density $\left(\rho_{p}\right)$, particle-size distributions, soil-moisture retention $[\theta(\psi)]$, saturated hydraulic conductivity, and hydraulic conductivity as a function of water content $[\mathrm{K}(\theta)]$. Table 1 summarizes properties including bulk density, calculated porosity, lab-saturated water content, saturated hydraulic conductivity, and U.S. Department of Agriculture texture classification (U.S. Department of Agriculture, 1951) for the 12 interbed core samples. In some cases the lab-saturated water content is slightly higher than the calculated porosity value, which may be due to the presence of excess water on top of the sample after the saturated hydraulic conductivity measurement. Unsaturated hydraulic conductivity and moisture retention data are presented in table 2 and figs. 4 and $\underline{5}$, respectively. Table 2 also contains the commonly used van Genuchten water retention parameters $\alpha$ and $n$ (van Genuchten, 1980) obtained using the RETention Curve (RETC) program (van Genuchten and others, 1991). Summarized particle-size distribution data are presented in table 3 and figure 6 . The cores analyzed in this study have a wide range in textures from gravelly sand to silt loam. Table 3 lists the texture class percentages and textural names for each sample based on the U.S. Department of Agriculture soil classification system (Soil Survey Staff, 1975).

The core samples in this study may be the most texturally diverse of any sample set analyzed at the INL. Seven of the twelve samples were assigned to the silt loam textural classification. One unexpected result is that five of these seven silt loam-textured samples have saturated hydraulic conductivity values more similar to sandy textured samples (approximately $10^{-4} \mathrm{~cm} / \mathrm{s}$ ) than typical silt loams. Perkins and Nimmo (2000), Perkins (2003), and Winfield (2003) reported $K_{\text {sat }}$ values for silt loam samples in the range of approximately $10^{-5}$ to $10^{-7} \mathrm{~cm} / \mathrm{s}$.

Table 1. USGS-140 core sample bulk properties and saturated hydraulic conductivity, Idaho National Laboratory, Idaho.

\begin{tabular}{cccccl}
\multicolumn{2}{l}{ (Abbreviations: m, meter; $\theta_{\text {sat }}$, saturated water content, $\mathrm{K}_{\text {sat }}$, saturated hydraulic conductivity) } \\
\hline $\begin{array}{c}\text { Sample depth } \\
\text { (m) }\end{array}$ & $\begin{array}{c}\text { Bulk } \\
\text { density }\end{array}$ & Porosity & $\theta_{\text {sat }}$ & $\mathbf{K}_{\text {sat }}$ & \multicolumn{1}{c}{ Texture } \\
\hline 39.2 & 1.52 & 0.456 & 0.456 & $1.46 \mathrm{E}-04$ & sandy loam \\
51.6 & 1.52 & 0.436 & 0.435 & $8.97 \mathrm{E}-03$ & sandy loam \\
53.0 & 1.26 & 0.523 & 0.480 & $4.49 \mathrm{E}-03$ & sandy loam \\
54.3 & 1.54 & 0.429 & 0.443 & $7.60 \mathrm{E}-04$ & silt loam \\
55.9 & 1.57 & 0.428 & 0.428 & $1.74 \mathrm{E}-02$ & gravelly sand \\
56.1 & 1.67 & 0.390 & 0.394 & $3.56 \mathrm{E}-04$ & silt loam \\
70.0 & 1.61 & 0.432 & 0.432 & $6.58 \mathrm{E}-06$ & silt loam \\
71.4 & 1.58 & 0.435 & 0.435 & $3.56 \mathrm{E}-04$ & silt loam \\
71.6 & 1.81 & 0.313 & 0.313 & $1.25 \mathrm{E}-04$ & silt loam \\
72.2 & 1.62 & 0.389 & 0.401 & $1.32 \mathrm{E}-04$ & silt loam \\
72.5 & 1.80 & 0.349 & 0.348 & $7.51 \mathrm{E}-06$ & silt loam \\
84.3 & 1.64 & 0.393 & 0.393 & $5.60 \mathrm{E}-05$ & sand \\
\hline
\end{tabular}


Table 2. USGS-140 core sample hydraulic properties and van Genuchten (1980) parameters $\alpha$ (the scaling parameter, in units of $1 /$ centimeter) and $n$ (the shape parameter, unitless) , Idaho National Laboratory, Idaho.

(Abbreviations m, meters; centimeters per second, cm/s; cm-water, centimeters of water)

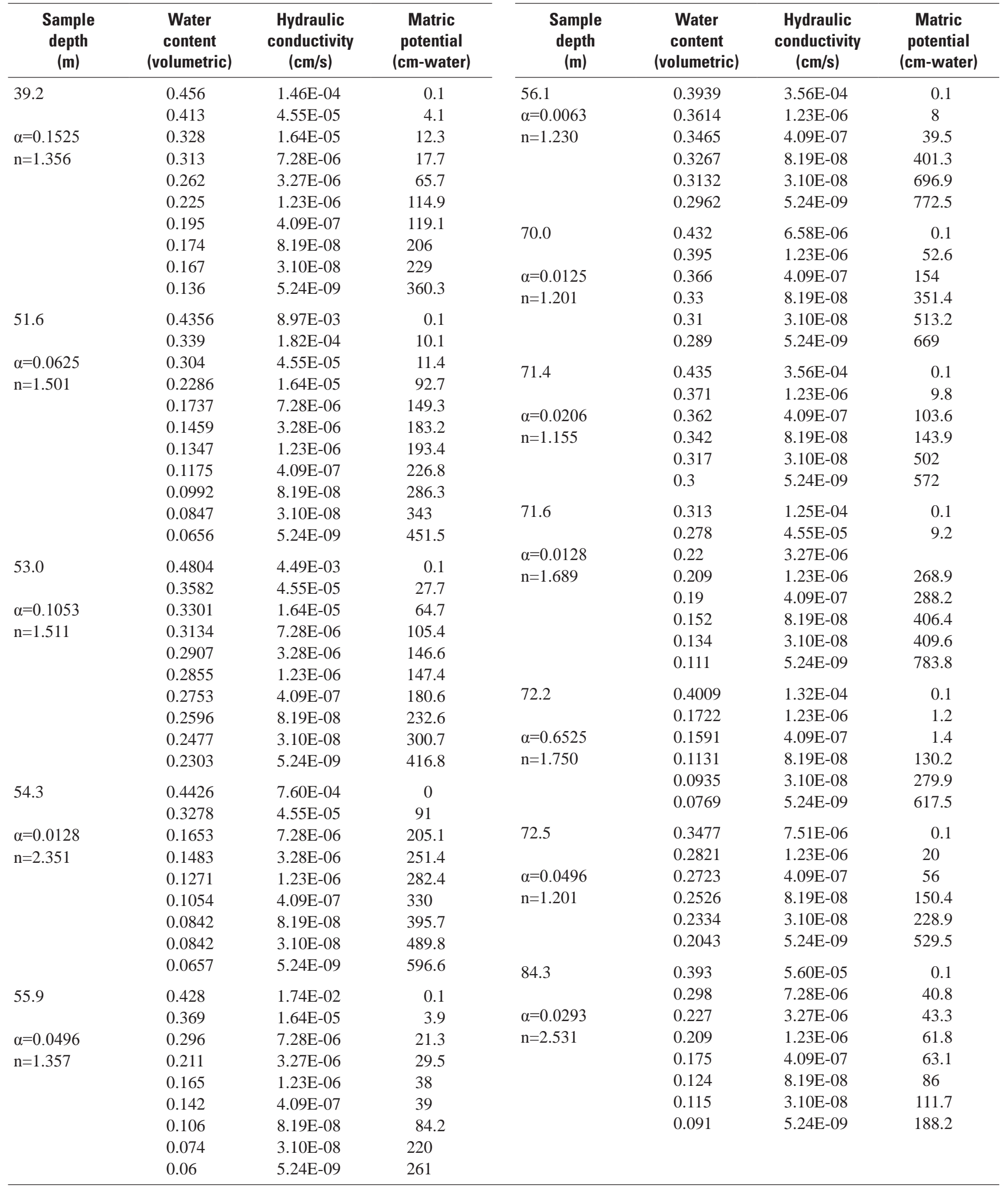




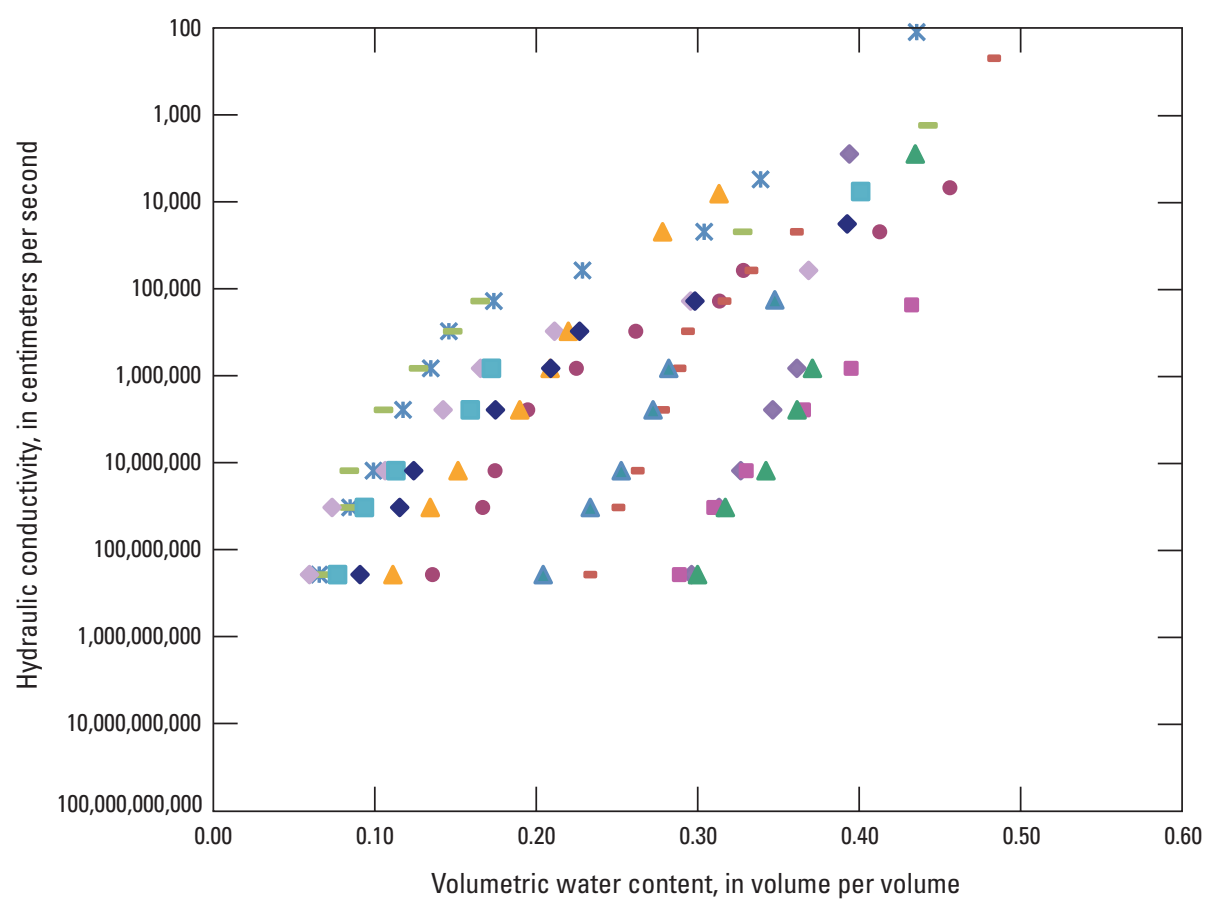

EXPLANATION

Sample depth, in meters

- $39.2-70.0$

* $51.6 \triangle 71.4$

$-53.0 \Delta 71.6$

$-54.3 \square 72.2$

$55.9 \Delta 72.5$

$\checkmark 56.1 \diamond 84.3$

Figure 4. Measured unsaturated hydraulic conductivity curves for samples from borehole USGS-140, Idaho National Laboratory, Idaho. Volumetric water content is measured as volume of water per total sample volume.

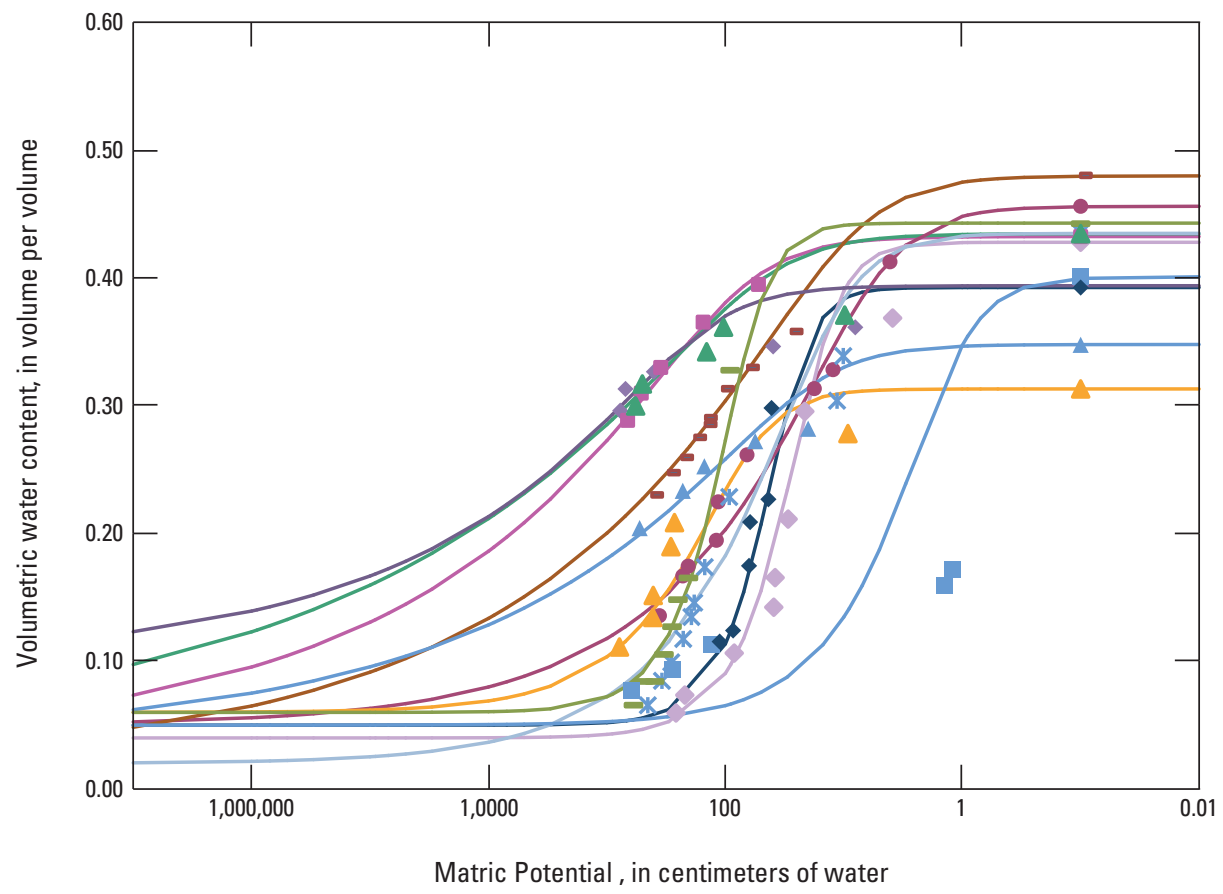

EXPLANATION

Sample depth, in meters

- $39.2 \square 70.0$

* $51.6 \triangle 71.4$

- $53.0 \triangle 71.6$

$-54.3 \square 72.2$

$55.9 \diamond 72.5$

$\checkmark 56.1 \triangle 84.3$

Figure 5. Measured water retention curves for samples from borehole USGS-140, Idaho National Laboratory, Idaho. Data were fit with the van Genuchten (1980) model. 


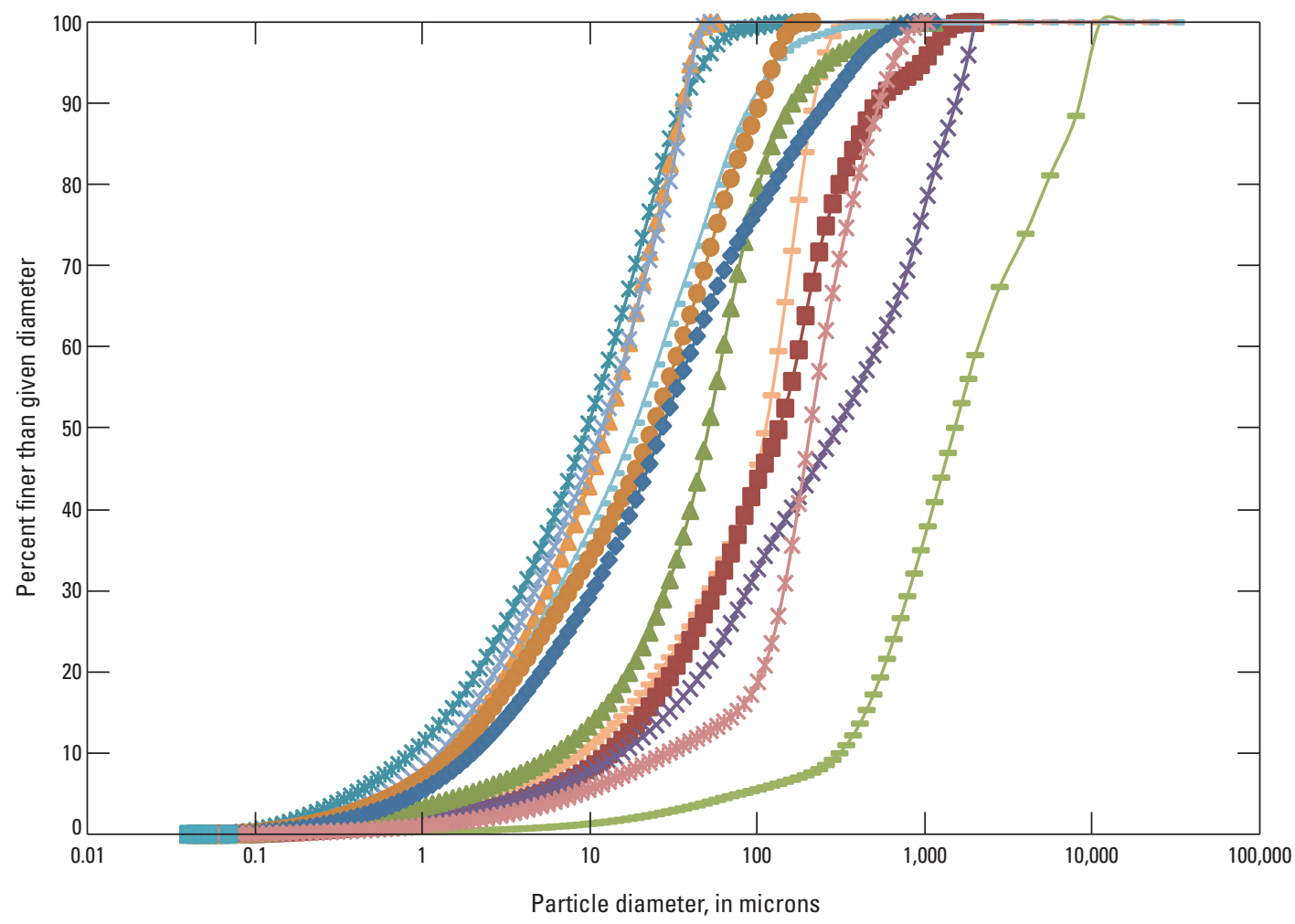

EXPLANATION

\begin{tabular}{|c|c|c|c|}
\hline \multicolumn{4}{|c|}{ Sample depth, in meters } \\
\hline & 39.2 , sandy loam & - & 70.0 , silt loam \\
\hline- & 51.6, sandy loam & 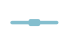 & 71.4 , silt loam \\
\hline$\leftarrow$ & 53.0, sandy loam & $*$ & 71.6, silt loam \\
\hline & 54.3, silt loam & $\rightarrow$ & 72.2 , silt loam \\
\hline & 55.9 , gravelly sand & $\leadsto$ & 72.5 , silt loam \\
\hline & 56.1 , silt loam & * & 84.3, sand \\
\hline
\end{tabular}

Figure 6. Measured particle size distributions for core samples from borehole USGS-140, Idaho National Laboratory, Idaho. 
Table 3. Texture and textural class information for core and bulk samples from USGS-140, Idaho National Laboratory, Idaho.

(Particle data are in millimeters. Abbreviations m, meters; mm, millimeters; >, greater than; <, less than)

\begin{tabular}{ccccccl}
\hline $\begin{array}{c}\text { Sample depth } \\
(\mathbf{m})\end{array}$ & $\begin{array}{c}\text { Sample } \\
\text { type }\end{array}$ & $\begin{array}{c}\text { Clay } \\
(<\mathbf{0 . 0 0 2} \mathbf{~ m m})\end{array}$ & $\begin{array}{c}\text { Silt } \\
\mathbf{( 0 . 0 0 2 - 0 . 0 5} \mathbf{~ m m})\end{array}$ & $\begin{array}{c}\text { Sand } \\
(\mathbf{0 . 0 5}-\mathbf{2} \mathbf{~ m m})\end{array}$ & $\begin{array}{c}\text { Gravel } \\
(>\mathbf{2} \mathbf{~ m m})\end{array}$ & \multicolumn{1}{c}{ Texture } \\
\hline 39.2 & core & 3.81 & 28.23 & 67.96 & 0 & sandy loam \\
50.5 & bulk & 4.95 & 18.54 & 76.55 & 0 & loamy sand \\
51.2 & bulk & 18.6 & 81.4 & 0 & 0 & silt loam \\
51.6 & core & 2.97 & 27.63 & 69.36 & 0 & sandy loam \\
52.3 & bulk & 4.06 & 23.63 & 72.32 & 0 & loamy sand \\
52.7 & bulk & 8.27 & 45.66 & 46.07 & 0 & sandy loam \\
52.8 & bulk & 7.44 & 44.27 & 48.27 & 0 & sandy loam \\
53.0 & bcore & 3.29 & 19.55 & 77.19 & 0 & sandy loam \\
54.3 & core & 5.74 & 50.11 & 44.13 & 0 & silt loam \\
55.8 & bulk & 0.52 & 3.36 & 60.34 & 35.77 & gravelly sand \\
55.9 & core & 0.48 & 3.53 & 54.99 & 41.01 & gravelly sand \\
56.1 & core & 21.8 & 75.5 & 2.67 & 0 & silt loam \\
65.5 & bulk & 24.45 & 74.95 & 0 & 0.6 & silt loam \\
70.0 & core & 14.81 & 85.08 & 0.04 & 0.04 & silt loam \\
70.1 & bulk & 24.6 & 75.4 & 0 & 0 & silt loam \\
71.4 & core & 15.62 & 64.36 & 20 & 0 & silt loam \\
71.6 & core & 16.78 & 83.19 & 0.05 & 0 & silt loam \\
72.2 & core & 14.67 & 60.56 & 24.77 & 0 & silt loam \\
72.5 & core & 11.69 & 55.82 & 32.48 & 0 & silt loam \\
72.8 & bulk & 15.34 & 65.86 & 18.79 & 0 & silt loam \\
84.3 & core & 1.88 & 10.88 & 87.25 & 0 & sand \\
92.4 & bulk & 5.51 & 21.31 & 0 & 73.17 & gravelly loamy sand \\
93.0 & bulk & 20.74 & 38.41 & 0 & 40.84 & gravelly loam \\
98.5 & bulk & 23.1 & 72.28 & 0 & 4.6 & silt loam \\
\hline
\end{tabular}

\section{Property-Transfer Modeling}

Figure 7 shows observed and property transfer modelpredicted saturated water content $\left(\theta_{\text {sat }}\right)$, saturated hydraulic conductivity $\left(K_{\text {sat }}\right)$, and the Rossi-Nimmo model parameters $\lambda$ and $\psi_{0}$. The best agreement between measured and modeled parameters is for $K_{\text {sat }}$ with an RMSE value of 0.0039. $\theta_{\text {sat }}$ also exhibits a strong agreement with an RMSE value of 0.0383.

The curve shape parameter $\lambda$ has a value of 0.2861 , while $\psi_{0}$ has the highest RMSE value of 244.75. The model as it was originally formulated performs well for 3 of the 4 parameters of interest. The $\psi_{0}$ parameter is over-predicted for 6 of the 12 samples. The six samples that the model does not predict parameters well for are all silt loam in texture, which is the texture of the majority of the samples used in formulating the property-transfer model. As previously mentioned, measured $K_{\text {sat }}$ values were higher than expected for silt loam textured samples, however the model still does well in the prediction of $K_{\text {sat }}$. There may have been a structural effect that is unique to those particular silt loam samples that influences the matric potential at which those samples begin to drain which is related to the $\psi_{0}$ parameter.

The data also were evaluated with the Pearson coefficient of correlation, $\mathrm{r}$. The highest correlation is for $K_{\text {sat }}$ with an r value of 0.922. $\theta_{\text {sat }}$ also exhibits a strong linear correlation with an $r$ value of 0.892 . The curve shape parameter $\lambda$ has a value of 0.731 , while $\psi_{0}$ has the lowest $r$ value of 0.528 . Though the model does not perform as well in predicting $\psi_{0}$, there is some linearity between the modeled and observed values. 

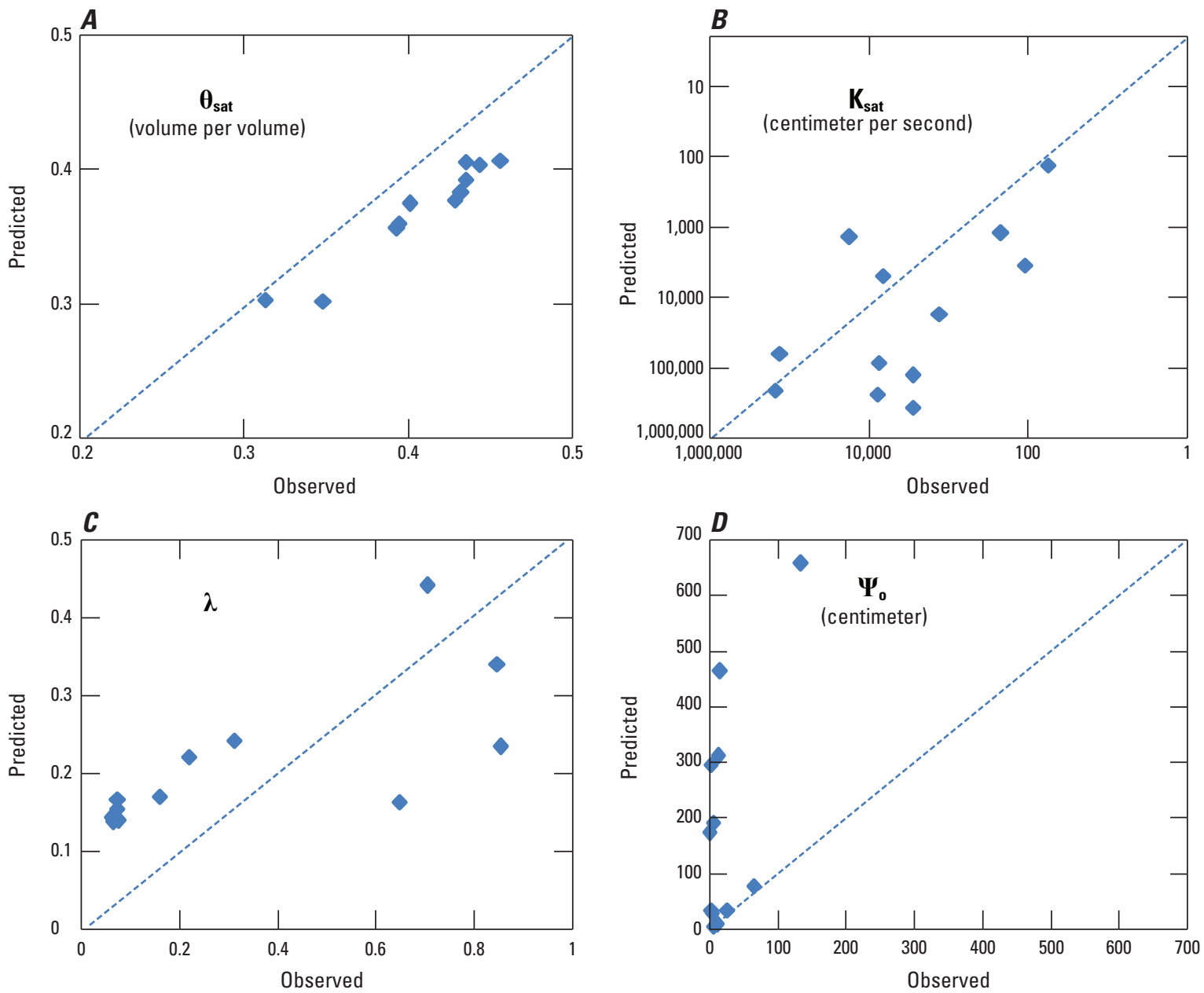

Figure 7. Observed and property transfer model predicted $(A)$ saturated water content $\left(\theta_{\text {sat }}\right),(B)$ saturated hydraulic conductivity $\left(K_{\text {sat }}\right)$, and $(C$ and $D)$ Rossi-Nimmo model parameters $\lambda$ and $\mathrm{y}_{0}$. The dashed line represents a perfect linear correlation between observed and predicted values.

\section{Summary}

Sedimentary interbed properties are known to affect water flow and contaminant transport in the Idaho National Laboratory unsaturated zone. Characterization of the sedimentary interbeds below the future site of the proposed Remote Handled Low-Level Waste facility, which is intended for the long-term disposal of low-level radioactive waste, is important in numerical modeling to evaluate groundwater flow and contaminant transport. Twelve core samples from the sedimentary interbeds were collected for laboratory analysis of hydraulic properties, which also were used for further testing of the property-transfer modeling approach. The 12 core samples analyzed in this study show a wide variety of hydraulic and bulk properties and include some of the coarsest textured samples measured in the laboratory. Evaluation of the site-specific property-transfer model shows that the model does well for predicting saturated water content, saturated hydraulic conductivity, and the $\lambda$ parameter which are required in modeling water flow and contaminant transport through the unsaturated zone. 


\section{References Cited}

Anderson, S.R., 1991, Stratigraphy of the unsaturated zone and uppermost part of the Snake River Plain aquifer at the Idaho Chemical Processing Plant and Test Reactors Area, Idaho National Engineering Laboratory, Idaho: U.S. Geological Survey Water-Resources Investigations Report 91-4010 (DOE/ID-22095), 71 p.

Anderson, S.R., Liszewski, M.J., and Ackerman, D.J., 1996, Thickness of surficial sediment at and near the Idaho National Engineering Laboratory, Idaho, : U.S. Geological Survey Open-File Report 96-330 (DOE/ID-22128), 16 p.

Blake, G.R., and Hartge, K.H., 1986, Particle density, in Klute, A., ed., Methods of soil analysis, part 1-Physical and mineralogical methods (2nd ed.): Madison, Wisconsin, Soil Science Society of America, Soil Science Society of America Book Series No. 5, p. 377-382.

Conca, J.L., and Wright, J.V., 1998, The UFA method for rapid, direct measurements of unsaturated soil transport: Australian Journal of Soil Research, v. 36, p. 291-315.

Davis, L.C., Bartholomay, R.C., and Rattray, G.W., 2013, An update of hydrologic conditions and distribution of selected constituents in water, Snake River Plain aquifer and perched groundwater zones, Idaho National Laboratory, Idaho, emphasis 2009-11: U.S. Geological Survey Scientific Investigations Report 2013-5214 (DOE/ID-22226), 90 p.

Gee, G.W., and Or, D., 2002, Particle-size analysis, in Dane, J.H., and Topp, G.C., eds., Methods of soil analysis, Part 4-Physical methods: Madison, Wisconsin, Soil Science Society of America, Soil Science Society of America Book Series No. 5, p. 255-293.

Hackett, B., Pelton, J., and Brockway, C., 1986, Geohydrologic story of the eastern Snake River Plain and the Idaho National Engineering Laboratory: U.S. Department of Energy, Idaho Operations Office, Idaho National Engineering Laboratory, 32 p.

Klute, A, and Dirkson, C., 1986, Hydraulic conductivity and diffusivity, laboratory methods, in Klute, A., ed., Methods of soil analysis, Part 1—Physical and mineralogical methods (2nd ed.): Madison, Wisconsin, Soil Science Society of America, Soil Science Society of America Book Series No. 5, p. 687-732.

Nimmo, J.R., Perkins, K.S., and Lewis, A.M., 2002, Steadystate centrifuge, in Dane, J.H. and Topp, G.C., eds., Methods of soil analysis, Part 4-Physical methods: Madison, Wisconsin, Soil Science Society of America, Soil Science Society of America Book Series No. 5, p. 903-916.
Nimmo, J.R., Stonestrom, D.A., and Akstin, K.C., 1994, The feasibility of recharge rate measurements using the steady state centrifuge method: Soil Science Society of America Journal, v. 58, p.49-56.

Perkins, K.S., 2003, Measurement of sedimentary interbed hydraulic properties and their hydrologic influence near the Idaho Nuclear Engineering and Technology Center at the Idaho National Engineering and Environmental Laboratory: U.S. Geological Survey Water-Resources Investigations Report, 03-4048, 19 p.

Perkins, K.S., 2008, Laboratory-measured and propertytransfer modeled saturated hydraulic conductivity of Snake River Plain aquifer sediments at the Idaho National Laboratory, Idaho: USGS Scientific Investigations Report 2008-5169, 13 p.

Perkins, K.S., and Nimmo, J.R., 2000, Measurement of hydraulic properties of the B-C interbed and their influence on contaminant transport in the unsaturated zone at the Idaho National Engineering and Environmental Laboratory: U.S. Geological Survey Water-Resources Investigations Report, 00-4073.

Perkins, K.S. and Winfield, K.A., 2007, Property transfer modeling to estimate unsaturated hydraulic conductivity of deep sediments at the Idaho National Laboratory, Idaho: U.S. Geological Survey Scientific Investigations Report 2007-5093, 22 p.

Richards, L.A., 1931, Capillary conduction of liquids through porous mediums, Physics, v. 1, no. 5, p. 318-333.

Rossi, C., and Nimmo, J.R., 1994, Modeling of soil water retention from saturation to oven dryness: Water Resources Research, v. 30, p. 701-708.

Soil Survey Staff, 1975, Soil taxonomy-A basic system of soil classification for making and interpreting soil survey: Washington D.C., Soil Conservation Office, U.S. Department of Agriculture Handbook no. 436 (1975).

Twining, B.V., Bartholomay, R.C., and Hodges, M.K.V., 2014, Completion summary for boreholes USGS 140 and USGS 141 near the Advanced Test Reactor Complex, Idaho National Laboratory, Idaho: U.S. Geological Survey Scientific Investigations Report 2014-5098 (DOE/ ID-22229), $40 \mathrm{p}$.

U.S. Department of Agriculture, 1951, Soil survey manual; U.S. Department of Agriculture, p. 208.

U.S. Department of Energy, 1989, Climatography of the Idaho National Engineering Laboratory, DOE/ID-12118, Rev. 0: U.S. Department of Energy Idaho Operations Office, December 1989. 
U.S. Department of Energy, 2004, Long-term monitoring plan for operable unit 3-13, group 5, Snake River Plain aquifer, DOE/ID-10783, Rev. 3: U.S. Department of Energy Idaho Operations Office, August 2004.

U.S. Department of Energy, 2007, Record of decision for tank farm soil and INTEC groundwater, DOE-ID 11296, Rev. 0: U.S. Department of Energy Idaho Operations Office, May, 2007.

van Genuchten, M.Th., 1980, A closed-form equation for predicting the hydraulic conductivity of unsaturated soils: Soil Science Society of America Journal, v. 44, p 892-898.

van Genuchten, M.Th., Leij, F.J., and Yates, S.R., 1991, The RETC Code for quantifying the hydraulic functions of unsaturated soils: U.S. Environmental Protection Agency (EPA/600/2- 91/065), 85 p.
Winfield, K.A., 2003, Spatial variability of sedimentary interbed properties near the Idaho Nuclear Technology and Engineering Center at the Idaho National Engineering and Environmental Laboratory, Idaho: U.S. Geological Survey Water-Resources Investigations Report, 03-4142, 36 p.

Winfield, K.A., 2005, Development of property-transfer models for estimating the hydraulic properties of deep sediments at the Idaho National Engineering and Environmental Laboratory, Idaho: U.S. Geological Survey Scientific Investigations Report 2005-5114, 49 p. 

Publishing support provided by the U.S. Geological Survey Science Publishing Network, Tacoma Publishing Service Center

For more information concerning the research in this report, contact the Director, Idaho Water Science Center

U.S. Geological Survey

230 Collins Road

Boise, Idaho 83702

http://id.water.usgs.gov 


\section{๕र}

믐

ํㅡㄹ

웋

c)

공

产

을

오

ํㅗㅀ

言

꿍

弯.

$\stackrel{0}{\circ}$

묭

is 